\title{
Dispersal of Cotesia flavipes in sugarcane field and implications for parasitoid releases
}

\author{
Leila Luci Dinardo-Miranda ( $\left.{ }^{\text {* }}\right)$; Juliano Vilela Fracasso ('); Viviane Pereira da Costa ('); \\ Diego Olympio Teixeira Lopes $\left(^{2}\right)$
}

(') Instituto Agronômico (IAC), Centro de Cana, Rodovia SP 333, km 321, 14100-970 Ribeirão Preto (SP), Brasil.

(2) Universidade Estadual Paulista (UNESP), Faculdade de Ciências Agrárias e Veterinárias, Departamento de Fitossanidade, Via de Acesso Prof. Paulo Donato Castellane, s/n, 14884-900 Jaboticabal (SP), Brasil.

(*) Corresponding author: leiladinardo@iac.sp.gov.br

Received: Oct. 30, 2013; Accepted: Apr. 28, 2014

\begin{abstract}
Diatraea saccharalis Fabr. (Lepidoptera: Crambidae) is a major sugarcane pest in Brazil. The management of infested areas is based on the release of Cotesia flavipes (Cameron) (Hymenoptera: Braconidae), a parasitoid of D. saccharalis larvae, but there are doubts about the effectiveness of $C$. flavipes, primarily regarding its rate of dispersal in sugarcane fields. Thus, the objective of this study was to evaluate the dispersal of $C$. flavipes in a sugarcane field and suggest a release method that provides higher parasitoid efficiency. The study was carried out in four areas of approximately 1 ha, in which stalk pieces containing 20 D. saccharalis larvae were distributed in a rectangular grid, and 12,000 C. flavipes adults were released at four points, that were $50 \mathrm{~m}$ apart and $25 \mathrm{~m}$ from the field border. Three days later, the $D$. saccharalis larvae were recovered and kept in the laboratory until they reached pupal stage or C. flavipes emergence. Parasitism varied from $13.2 \%$ to $42.8 \%$. The random distribution of parasitized larvae was found in one assay. In three areas, the parasitized larvae showed an aggregated distribution, with a range of 15 to $25 \mathrm{~m}$. Since the parasite's success is directly linked to parasitoid dispersion, it would be interesting to move the release points to $30 \mathrm{~m}$ from each other because the dispersal may happen in a $15 \mathrm{~m}$ radius.
\end{abstract}

Key words: sugarcane borer, Diatraea saccharalis, biological control, aggregation, pest management.

\section{Dispersão de Cotesia flavipes em canavial e implicações para a liberação do parasitoide}

\section{Resumo}

Diatraea saccharalis Fabr. (Lepidoptera: Crambidae) é uma das principais pragas da cana-de-açúcar no Brasil. O manejo de áreas infestadas é baseado na liberação de Cotesia flavipes (Cameron) (Hymenoptera: Braconidae), um parasitoide de larvas de $D$. saccharalis, mas existem dúvidas a respeito da eficiência de $C$. flavipes, principalmente em relação à sua capacidade de dispersão em campo. Assim, o objetivo deste estudo foi avaliar a capacidade de dispersão de $C$. flavipes em canaviais e sugerir um método de liberação que propicie maior eficiência do parasitoide. O estudo foi conduzido em quatro áreas de aproximadamente 1 ha, e, em cada uma, pedaços de colmos contendo 20 larvas de $D$. saccharalis foram distribuídos em grid retangular e 12 mil adultos de $C$. flavipes foram liberados em quatro pontos, separados entre si por $50 \mathrm{~m}$ e a $25 \mathrm{~m}$ das bordaduras do campo. Três dias depois, as larvas de $D$. saccharalis foram removidas e mantidas em laboratório até se transformarem em pupas ou até a emergência de C. flavipes. O parasitismo variou de 13,2\% a 42,8\%. As larvas parasitadas se distribuíram ao acaso em uma área e em três áreas a distribuição foi agregada, com alcance de 15 a 25 m. Visto que o sucesso do parasitismo está diretamente ligado à dispersão do parasitoide, sugere-se que os pontos de liberação estejam distantes entre si 30 m, visto que o raio de dispersão pode ser de $15 \mathrm{~m}$.

Palavras-chave: broca-da-cana, Diatraea saccharalis, controle biológico, agregação, manejo de pragas.

\section{INTRODUCTION}

The sugarcane borer, Diatraea saccharalis Fabr. (Lepidoptera: Crambidae), is one of the most important insect pests of sugarcane in Brazil due to the a sharp reduction in sugarcane productivity and quality promoted by larvae attack (Botelho and Macedo, 2002; DinardoMiranda, 2008).

In Brazil, the management of infested areas is based on biological control, particularly those involving the larvae parasitoid Cotesia flavipes (Cameron) (Hymenoptera: Braconidae), a gregarious endoparasitoid introduced from Trinidad, India and Pakistan at the beginning of the 1970s (Botelho and Macedo, 2002). Since then, C. flavipes has been reared in the laboratories of sugarcane mills and intensively released into the fields.

C. flavipes are released into infested fields throughout the year, although these releases are more frequent during 
spring and summer when $D$. saccharalis populations increase. The released quantity of $C$. flavipes depends on the pest population, but is generally 6,000 adults (males and females) per hectare, one or more times per year (Botelho and Macedo, 2002; Dinardo-Miranda, 2008).

Botelho et al. (1980) ${ }^{1}$ estimated that the dispersion of $C$. flavipes adults varies from 25 to $48 \mathrm{~m}(34 \mathrm{~m}$ on average), thus, these wasps are usually released at four points per hectare, approximately $50 \mathrm{~m}$ apart from each other (Almeida et al., 1997) ${ }^{2}$.

For many years, $C$. flavipes has been reported as an efficient biological control agent for $D$. saccharalis (Botelho and Macedo, 2002; Dinardo-Miranda, 2008). However, reports of areas with high borer populations have been frequent despite the continuous release of the parasitoid. One of the primary reasons for this growth in the sugarcane borer population is that newly released cultivars are more susceptible to the pest than are the older ones. However, there are doubts about the effectiveness of $C$. flavipes in relation to pest control, mainly regarding the rate of its dispersal in a sugarcane field.

Thus, the objectives of this study were to evaluate the dispersal of $C$. flavipes in sugarcane fields, by examining the distribution of parasitized hosts, and to suggest a release method that provides greater parasitoid efficiency.

\section{MATERIAL AND METHODS}

The study was carried out in Ribeirão Preto (SP), Brazil $\left(21^{\circ} 12^{\prime} 56^{\prime \prime} \mathrm{S}\right.$ and $47^{\circ} 52^{\prime} 38^{\prime \prime} \mathrm{W}$, at an altitude of $\left.630 \mathrm{~m}\right)$ in an area of approximately 50 ha of 7-month-old sugarcane field (RB857515 cultivar). During previous years, this area had been cultivated with pasture and $C$. flavipes had never been released. In this area, four fields of approximately 1 ha $(94.5 \times 100 \mathrm{~m})$ each that were separated from each other by at least 200 meters were demarcated. An experiment was conducted in each delimited area (study field).

Stalks of the IACSP95-5094 sugarcane cultivar were cut into five internodal pieces. In each of the four superior internodes, a hole that was $0.5 \mathrm{~cm}$ in diameter was made using a drilling machine. A 14-day-old and 2-cm-long $D$. saccharalis larva from the laboratory rearing was put into each hole. Thus, each stalk contained four larvae. Because C. flavipes responds strongly to the odor of the frass generated by D. saccharalis larvae (Van Leerdam et al.,

${ }^{1}$ BOTELHO, P.S.M.; MACEDO, N.; MENDES, A.C.; SILVEIRA NETO, S. Aspects of the population dynamics of Apanteles flavipes (Cameron) and support capacity of its host Diatraea saccharalis (Fabr.) In: CONGRESS OF INTERNATIONAL SOCIETY OF SUGARCANE TECHNOLOGISTS, 17., 1980, Manila. Proceedings...

${ }^{2}$ ALMEIDA, L.C.; ARRIGONI, E.B.; RODRIGUES FILHO, J.P. Modelo de análise econômica para avaliação do controle biológico da broca da cana-de-açúcar, Diatraea saccharalis. In: SEMINÁRIO COPERSUCAR DE TECNOLOGIA AGRONÔMICA, 7., 1997. Anais...
1986), the stalks remained in the laboratory for one day after their preparation to allow for larval establishment and frass production.

Each field of approximately 1 ha was divided into 100 plots measuring $10.5 \times 10.0 \mathrm{~m}$. A group of five stalks containing 20 larvae was placed in the center of every plot. The stalk pieces were placed together in the sugarcane row, standing between the crops stalks. Therefore, the D. saccharalis larvae were distributed in a rectangular grid measuring $10.5 \times 10.0 \mathrm{~m}$, except in field 2 . In a portion of field 2 ( $10 \%$ of the field), the stalk pieces were distributed in a rectangular grid measuring $21.0 \times 10.0 \mathrm{~m}$ and in a rectangular grid measuring $10.5 \times 10.0 \mathrm{~m}$ in another portion of field 2. Thus, in fields 1, 3, and 4, 2,000 larvae were distributed, while in field 2, 1,800 larvae were distributed.

Experiments on fields 1, 2, 3, and 4 were initiated on January 13, 2011, February 2, 2011, February 15, 2011, and March 15, 2011, respectively.

Just after the stalks containing $D$. saccharalis larvae had been distributed in the experimental fields, 12,000 C. flavipes adults were released at four points $(3,000$ adults in each point) that were $50 \mathrm{~m}$ apart and $25 \mathrm{~m}$ from the field border. The $C$. flavipes were released at 10 a.m. on a cloudy morning (fields 1 and 3), at 10 a.m. on a sunny morning (field 2), and at 4 p.m. on a sunny afternoon (field 4).

The parasitoids were obtained from a large laboratory rearing in which the sugarcane borer was used as a host. When the parasitoids were in the pupal stage, they were transferred to plastic glasses at the rate of 1,500 individuals per glass. The glasses were capped and maintained in the laboratory at $25^{\circ} \mathrm{C}$ for 1 or 2 days, until approximately $80 \%$ of adults had emerged (Cano et al., 2006). Since in commercial sugarcane fields in Brazil, C. flavipes are released into fields when approximately $80 \%$ of adults had emerged (Botelho and Macedo, 2002), the same criterion was used in these experiments.

The borers were exposed to the $C$. flavipes parasite for three days, after which all stalks were collected, identified and taken to the laboratory, where the stalks were carefully opened to remove the larvae. Each recovered larva was transferred to a plastic Petri dish containing an artificial diet described by King and Harley (1985).

The Petri dishes were kept in a climatized room $\left(25 \pm 1{ }^{\circ} \mathrm{C}\right.$, $70 \pm 10 \%$ relative humidity, $12 \mathrm{~h}$ photophase) until the emergence of $C$. flavipes or the $D$. saccharalis. The larvae that were parasitized in each sampling grid point were counted. In fields 2, 3 and 4, C. flavipes males and females emerged from each parasitized borer were counted.

During each assay carrying out, some weather parameters (air temperature, air relative humidity, total solar radiation an rainfall volume) were recorded.

The data from the parasitized borers per point, in each field, were initially analyzed by descriptive statistics; the mean, standard deviation, variation coefficient, maximum 
and minimum values, skewness and kurtosis were calculated. To verify the hypothesis of the normality of the data, the Shapiro and Wilk (1965) test was carried out. The Morisita dispersal indexes and the variance/mean ratio were calculated, as described by Silveira Neto et al. (1976).

Subsequently, geostatistical analyses of the data were completed using a semivariogram and kriging interpolation to construct maps, as described by Vieira et al. (1983). The semivariogram analyses were conducted using the Geostat 1.0 software (Vieira et al., 1983) and they were fitted to the model which gave the best coefficient of determination $\left(\mathrm{R}^{2}\right)$. From the fitted models, the following semivariogram parameters were taken: nugget effect $\left(\mathrm{C}_{0}\right)$, which represents the random variability being an indicative of shorter distance variability; sill $\left(\mathrm{C}_{0}+\mathrm{C}_{1}\right)$, which is the semivariance value in which the semivariogram curve stabilizes; range (a), the distance at which the sill is reached which defines the spatial dependence limit. The $\mathrm{C}_{1}$ value represents the structured spatial variability of the data.

The ratio between nugget effect and sill $\left(\mathrm{C}_{0} / \mathrm{C}_{0}+\mathrm{C}_{1}\right)$, expressed in percent, was used in order to classify the spatial dependence of the studied properties. According to Cambardella et al. (1994), the $\left(\mathrm{C}_{0} / \mathrm{C}_{0}+\mathrm{C}_{1}\right)$ ratio can be used to classify the spatial dependence in strong (ratio $<25 \%$ ), moderate $(26 \%<$ ratio $<75 \%)$ and weak (ratio $>75 \%)$.

Based on the models fitted to the semivariograms, the jackknifing test was used to verify whether the estimates of the semivariogram parameters were adequate and to estimate the number of neighbors that should be used in the kriging interpolation (Vieira, 2000). Once the parameters for the model were validated and the adequate number of neighbors was determined, the values were interpolated by the kriging method for the locations that were not measured using Geostat (Vieira et al., 2002). The kriging-estimated values were used in the Surfer 7.0 software (Golden Software, 1999) to construct maps of the $D$. saccharalis parasitized larvae.

\section{RESULTS AND DISCUSSION}

Although 1,800 larvae (field 2) or 2,000 larvae (fields 1,3 , and 4) were distributed in each field, no more than $50 \%$ of these larvae were recovered (Table 1); the remaining larvae died or were lost. Poor handling of the larvae may have resulted in the death of many of then. Several earwigs and ants were found in the holes in the stalks, suggesting that a portion of the borers placed in those holes had been predated. In sugarcane, the natural enemies, including earwigs and ants, play an important role in reducing the population of $D$. saccharalis by predating its eggs and larvae (Degaspari et al., 1987).

Based on the recovered larvae from the field, parasitism varied from $13.2 \%$ (field 2) to $42.8 \%$ (field 3) (Table 1). These values are similar to those observed by other researchers under Brazilian conditions. Almeida et al. (1997), who studied several sugarcane areas from 1981 to 1996, verified that the average parasitism of $D$. saccharalis by $C$. flavipes ranged from $7 \%$ in 1984 to $37 \%$ in 1996 . Macedo and Araújo (2000) found parasitism by C. flavipes to be from 0 to $30 \%$ in a sugarcane field evaluated over two consecutive years. Botelho and Macedo (2002), upon analyzing data from the Barra sugarcane mill from 1975 to 2000, found that average parasitism was lower than $10 \%$ from 1975 to 1985, while from 1989 to 2000, it was between 40 and 60\%.

According to Botelho and Macedo (2002), parasitism values smaller than $20 \%$ are considered low. Thus, in this work, parasitism was considered low in 2 of 4 assays, despite a twofold increase in the quantity of parasitoids released compared to that of commercial operations.

Typically, in commercial sugarcane fields, approximately 6,000 adults per ha of $C$. flavipes are released when the D. saccharalis population is at most 3,000 suitable larvae per ha (Almeida et al., 1997; Botelho and Macedo, 2002). In this study, twice the typical quantity of $C$. flavipes adults was released because the pest also attacked the field in which the assays took place. This way, the released wasps could also parasitize the borers in the sugarcane field. Additionally, a higher number of parasitoids was released in an attempt to induce the insect to disperse farther in search of nonparasitized hosts because, according to Campos-Farinha et al. (2000), C. flavipes females prefer to lay eggs in larvae that have not yet been parasitized.

Several factors must have interfered with parasitoid efficiency during the assays, including the climatic conditions at the moment of release. According to Pinto and Parra

Table 1. Experimental field descriptive parameters

\begin{tabular}{|c|c|c|c|c|c|}
\hline \multirow{2}{*}{ Parameters } & & \multicolumn{4}{|c|}{ Field } \\
\hline & & 1 & 2 & 3 & 4 \\
\hline Larvae recovered in the area & & 999 & 803 & 794 & 947 \\
\hline Larvae recovering (\%) & & 50.0 & 44.6 & 39.7 & 47.4 \\
\hline Parasitized larvae & & 165 & 106 & 340 & 358 \\
\hline Parasitism (\%) & & 16.5 & 13.2 & 42.8 & 37.8 \\
\hline \multirow{3}{*}{$\begin{array}{l}\text { Cotesia flavipes emerged from each } \\
\text { parasitized larvae }\end{array}$} & Total & * & 44.7 & 42.5 & 33.9 \\
\hline & q & * & $31.9 \pm 2.1$ & $32.1 \pm 1.2$ & $26.6 \pm 0.9$ \\
\hline & $\hat{\sigma}$ & * & $12.8 \pm 1.5$ & $10.4 \pm 0.6$ & $7.3 \pm 0.4$ \\
\hline
\end{tabular}

*without estimation. 
(2002), temperature and humidity that diverge from those that are optimum to the parasitoid can reduce the lifespan of $C$. flavipes and, consequently, its parasitism capacity. Zhou and Overholt (2001) reported variations in C. flavipes establishment in different regions of Africa and attributed those variations to the climate differences between the areas, among other factors. Emana et al. (2004) and Emana (2007), working under controlled conditions with two populations of $C$. flavipes, one from India and another from Pakistan, found that, although there were differences between the populations, temperatures generally between 25 and 28 ${ }^{\circ} \mathrm{C}$ and a relative humidity from $60 \%$ to $70 \%$ resulted in high survival, greater female fecundity, and a greater number of descendants. Sétamou et al. (2002), studying the influence of temperature on C. flavipes behavior, concluded that better parasitoid performance under field conditions would be obtained when temperatures were between 26 and $30{ }^{\circ} \mathrm{C}$. Thus, possibly the average temperature and humidity conditions during the four assays (Table 2) were suitable for C. flavipes parasitism. However, while assay 2 was being carried out, the maximum absolute temperature was higher than the temperatures observed during the other assay. These high temperatures may have contributed, at least in part, to the lower parasitism observed in this field.

In field 2, the higher maximum absolute temperature is directly related to higher solar radiation during the three days in which the $D$. saccharalis larvae were exposed to $C$. flavipes parasitism (Table 2). In this assay, the $C$. flavipes release was performed at 10:00 a.m. on a sunny day with clear skies; the sky had few clouds during the following days, while in the other assays, the releases were performed under cloudy skies (fields 1 and 2) or in the afternoon (field 4). In field 2 , the total solar radiation was $17 \%, 17 \%$ and $43 \%$ higher than observed in fields 3, 4, and 1, respectively.

Despite the difference between the solar radiation values during the experiments, solar radiation may not be the direct cause of the low parasitism in field 2. Several studies indicate that high luminosity favors parasitoid dispersal and host localization, factors that would favor an increase in parasitism. For example, Elzen et al. (1987) worked with Microsplitis croceipes (Cresson) (Hymenoptera: Braconidae) and found that parasitoid fly frequency, in response to host stimuli (frass), was affected by light intensity or luminosity. Likewise, Gu and Dorn (2001), working under controlled conditions, found that the quantity of flights of Cotesia glomerata (L.) to infested plants was greater when the light intensity was also greater, suggesting that parasitoid performance could be reduced on cloudy days. Thus, in the present work, the higher total radiation during field 2 most likely had a positive, direct effect on parasitism. However, it is important to consider that solar radiation may have indirectly affected parasitism by altering the temperature; higher solar radiation resulted in a higher temperature. In assay 2 , it is likely that the indirect effect of solar radiation increasing the temperature and reducing parasitism was more pronounced than the direct effect.

In field 1 , the low parasitism found is most likely related to precipitation because in the first two days after the release, precipitation was from 21.6 and $30.5 \mathrm{~mm}$ (totaling $52.1 \mathrm{~mm}$ ). The rain may have hindered the spread of the parasitoid and, hence, reduced the parasitism. The effect of rain on parasitoid efficiency was evaluated by Weisser et al. (1997), who found that the number of aphid colonies visited by Aphidius rosae (Haliday) (Hymenoptera: Aphidiidae) decreased when the duration of the rain increased because long rainy periods would hinder or even decrease the demand by the host.

In field 4, although the rain volume was similar to that in assay 1 , the weather was mild in the two days after the release (totaling $13 \mathrm{~mm}$ ), with a higher volume $(45.2 \mathrm{~mm})$ only on the third day when most insects had most likely already dispersed and found a host.

An average of 33.9 (field 4) and 44.7 (field 2) C. flavipes adults emerged from every parasitized larvae, which is similar to the results of Potting et al. (1997), who found that the emergence of approximately 40 individuals was common. Campos-Farinha et al. (2000), Campos-Farinha and ChaudNeto (2002) and Scaglia et al. (2005) also observed adults emerging from each parasitized larvae in similar numbers in laboratory studies.

Among the emerged adults, females were predominant (sexual ratio $=0.75$ ). This female predominance among the C. flavipes descendants that emerged from $D$. saccharalis was also observed by several other researchers, such as CamposFarinha and Chaud-Netto (2000), Sétamou et al. (2005) and Yamaushi et al. (1997). These results indicate that, even though twice the standard quantity of $C$. flavipes adults had been released, there was no superparasitism.

According to Suzuki and Iwasa (1980), when the host/ parasitoid ratio is low, more than one female can lay eggs in the same host, characterizing superparasitism, which generally

Table 2. Weather parameters during each assay carrying out

\begin{tabular}{|c|c|c|c|c|c|c|c|}
\hline \multirow[b]{2}{*}{ Field } & \multicolumn{3}{|c|}{ Air temperature $\left({ }^{\circ} \mathrm{C}\right)$} & \multicolumn{2}{|c|}{ Air relative humidity (\%) } & \multirow{2}{*}{$\begin{array}{c}\text { Total solar } \\
\text { radiation( }\left(\mathrm{MJ} \mathrm{m}^{-2}\right)\end{array}$} & \multirow[b]{2}{*}{ Rain $(\mathbf{m m})$} \\
\hline & $\begin{array}{l}\text { Maximum } \\
\text { absolute }\end{array}$ & $\begin{array}{l}\text { Minimum } \\
\text { absolute }\end{array}$ & Average & $\begin{array}{c}\text { at } \\
\text { 7:00 a.m. }\end{array}$ & $\begin{array}{c}\text { at } \\
\text { 1:00 p.m. }\end{array}$ & & \\
\hline 1 & 30.6 & 19.4 & 24.0 & 92.0 & 81.6 & 48.05 & 63.3 \\
\hline 2 & 31.8 & 19.1 & 25.0 & 94.0 & 25.2 & 68.49 & 32.3 \\
\hline 3 & 29.8 & 19.3 & 24.7 & 94.3 & 60.0 & 58.63 & 10.9 \\
\hline 4 & 30.5 & 19.4 & 24.9 & 93.7 & 63.9 & 58.37 & 58.2 \\
\hline
\end{tabular}


increases the proportion of males in the progeny. CamposFarinha et al. (2000) also observed that in D. saccharalis that were parasitized more than once by $C$. flavipes, there was an increase in the male progeny.

In the four fields, the coefficients of variation were very high, with large differences between the maximum and minimum values of parasitized larvae at each point, indicating that there was variability in the parasitism ratio in the fields (Table 3).

The variance was greater than the mean in all fields (Table 3); thus, the variance/mean ratio was greater than 1, indicating an aggregated spatial distribution. However, it was observed in assay 1 that the variance/mean ratio value calculated (1.13) was less than that calculated in the other assays. According to Perecin and Barbosa (1994), variance/mean ratio values smaller than 1.20 indicate either less contagious or a random distribution. However, those same authors affirmed that when averages are too low, it is difficult to separate the distributions of contagious from random distributions. Thus, in field 1, the parasitized larva distribution was random. However, it is important to consider that the lack of detection of aggregation in this assay might have been due to low parasitism in the assay.

The random distribution of parasitized larvae in field 1 was confirmed by the Morisita index (Table 3): in this assay, the calculated variance/mean ratio value (1.07) was not significantly greater than 1 , indicating a non-contagious distribution. In the remaining fields, the Morisita index greater than 1 indicates that the parasitized larvae were distributed in an aggregated manner in the fields.
Skewness values near 0 and kurtosis near 3 indicate a normal distribution of the data. Field 2 had a lower discrepancy in these values (Table 3). As expected for this type of enumeration, data normality was rejected by the Shapiro and Wilk (1965) test, but, according to Cressie (1991), it is not necessary that data present a normal distribution to use geostatistical analysis; it is merely convenient that the distribution curve does not indicate a long tail, which would endanger the results. Thus, considering the previous analysis of these data, the studied variable had an appropriate distribution for geostatistical analysis.

Among the four calculated semivariograms (one for each field), the semivariogram for field 1 did not fit to any model (pure nugget effect, Table 4), suggesting that there was no aggregation in this case. This result supports the variance/ mean ratio and the Morisita index (Table 3).

In the other fields, the larvae parasitized by $C$. flavipes populations showed spatial dependence in all criteria: semivariogram, variance/mean ratio and Morisita index. The spherical model was best fitted to the semivariograms in fields 2 to 4 (Figure 1, Table 4). Although the observed $\mathrm{r}^{2}$ values were lower than 0.75 , the parameters estimated for the spherical model $\left(\mathrm{C}_{0}, \mathrm{C}_{1}\right.$, a) were endorsed by the jackknifing test because the mean values for the reduced errors were near zero and the values for the variance of reduced errors were near 1 (Table 4). The jackknifing test also revealed the ideal number of neighbors to be used in kriging. As a result, kriging was performed using 16 neighbors in assays 2 and 4 but 8 neighbors in assay 3 . The maps constructed based on the data are presented in the figure 2 .

Table 3. Statistical parameters of data of Diatraea saccharalis larvae parasitized by Cotesia flavipes

\begin{tabular}{|c|c|c|c|c|c|c|}
\hline Field & $\begin{array}{c}\text { Mean } \\
\text { (parasitized } \\
\text { larvae per point) }\end{array}$ & $\begin{array}{l}\text { Standart } \\
\text { deviation }\end{array}$ & Variance & $\begin{array}{l}\text { Coefficient of } \\
\text { variation (\%) }\end{array}$ & $\begin{array}{l}\text { Minimum } \\
\text { value }\end{array}$ & $\begin{array}{l}\text { Maximum } \\
\text { value }\end{array}$ \\
\hline 1 & 1.65 & 1.37 & 1.87 & 82.8 & 0 & 6 \\
\hline 2 & 1.18 & 1.45 & 2.10 & 123.1 & 0 & 7 \\
\hline 3 & 3.40 & 2.25 & 5.05 & 66.1 & 0 & 9 \\
\hline 4 & 3.58 & 2.63 & 6.95 & 73.6 & 0 & 11 \\
\hline Field & Skewness & Kurtosis & $\begin{array}{c}\text { Shapiro Wilk } \\
\text { test }\end{array}$ & $\begin{array}{c}\text { Variance/mean } \\
\text { ratio }\end{array}$ & Morisita index & \\
\hline 1 & 0.73 & -0.02 & $0.89^{* *}$ & 1.13 & $1.07^{\mathrm{NS}}$ & \\
\hline 2 & 1.72 & 3.42 & $0.78^{* *}$ & 1.78 & $1.67^{* *}$ & \\
\hline 3 & 0.38 & -0.56 & $0.94^{* *}$ & 1.49 & $1.48^{* *}$ & \\
\hline 4 & 0.68 & 0.01 & $0.94^{* *}$ & 1.94 & $1.94^{* *}$ & \\
\hline
\end{tabular}

Table 4. Parameters of fitted semivariogram and jackkinifing, coefficient of determination $\left(\mathrm{R}^{2}\right)$ and $\mathrm{C}_{0} /\left(\mathrm{C}_{0}+\mathrm{C}_{1}\right)$ ratio of each field

\begin{tabular}{|c|c|c|c|c|c|c|c|}
\hline \multirow[t]{2}{*}{ Field } & \multicolumn{3}{|c|}{ Semivariogram parameters } & \multicolumn{2}{|c|}{$\begin{array}{l}\text { Jackknifing parameters } \\
\text { (reduced errors) }\end{array}$} & \multirow[t]{2}{*}{$\mathbf{R}^{2}$} & \multirow{2}{*}{$C_{0} /\left(C_{0}+C_{1}\right)$} \\
\hline & $\mathrm{C}_{0}$ & $C_{1}$ & $a(m)$ & mean & variance & & \\
\hline 1 & \multicolumn{7}{|c|}{ Pure nugget effect } \\
\hline 2 & 1.5 & 0.65 & 15 & 0.0099 & 0.9660 & -0.007 & 0.70 \\
\hline 3 & 3.5 & 1.2 & 25 & 0.0092 & 1.0012 & 0.14 & 0.74 \\
\hline 4 & 0 & 6.4 & 17 & 0.0181 & 0.9461 & 0.67 & 0 \\
\hline
\end{tabular}


The portion of variability attributed to the spatial dependence, given by the $\mathrm{C}_{0} /\left(\mathrm{C}_{0}+\mathrm{C}_{1}\right)$ ratio, varied from 0 to 0.74 (Table 4 ). These values indicated a strong spatial dependence between the samples in assay 4 and moderate spatial dependence between fields 2 and 3 (Cambardella et al., 1994).

The range (a), which represents the distance up to which there is spatial dependence between samples, varied from $15 \mathrm{~m}$ (field 2) to $25 \mathrm{~m}$ (field 3, Table 4). Therefore, the parasitized larvae were concentrated in a 707 to $1,965 \mathrm{~m}^{2}$ area. In this
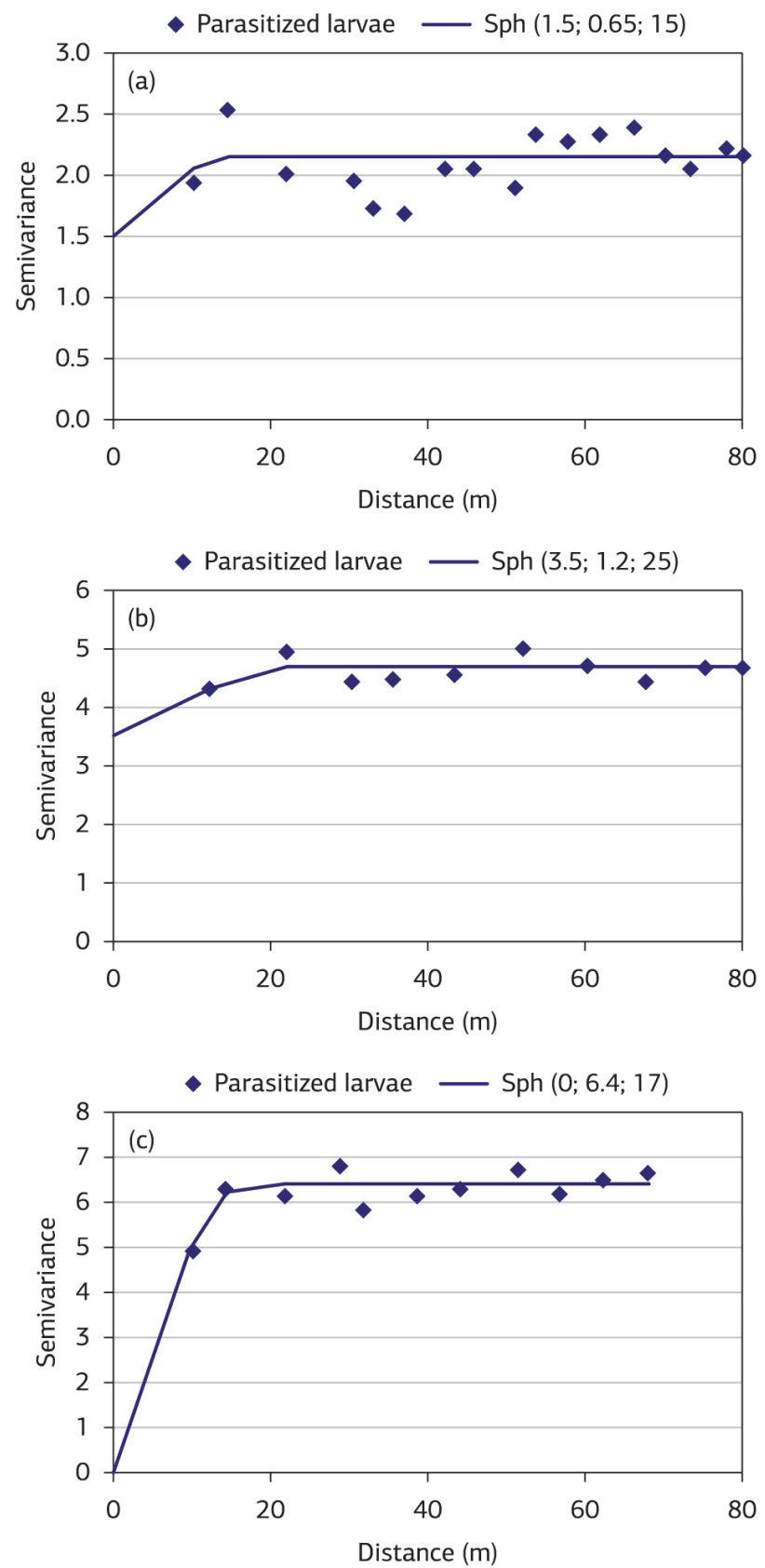

Figure 1. Semivariograms for populations of Diatraea saccharalis parasitized larvae by Cotesia flavipes in field 2 (a), 3(b) and 4 (c). Numbers in parenthesis are nugget effect value $\left(\mathrm{C}_{0}\right), \mathrm{C}_{1}$ and range (a) of spherical model (Sph). study, the range (a) represented the dispersal capability of most $C$. flavipes adults, although several specimens may have presented greater dispersal capabilities. This finding is consistent with the work of Sallam et al. (2001), who studied C. flavipes dispersal in maize fields in Kenya and

(a)

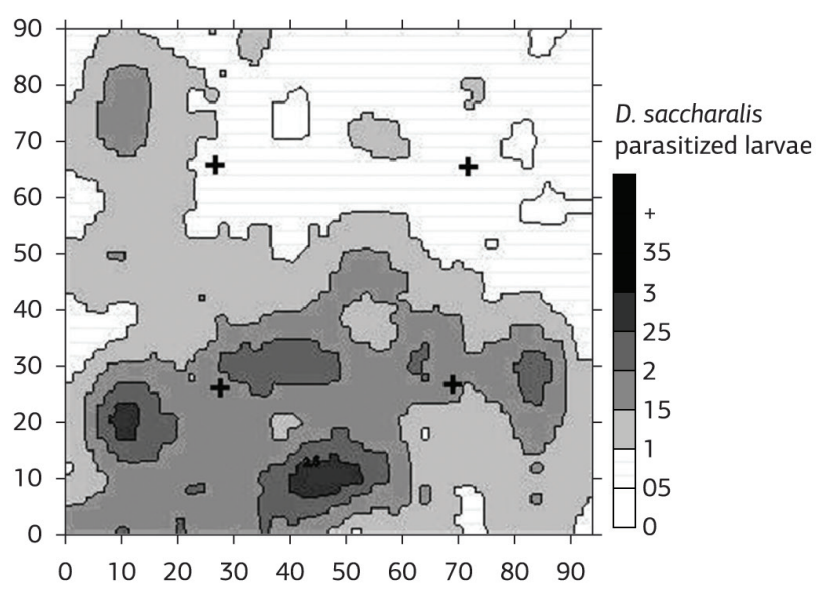

(b)

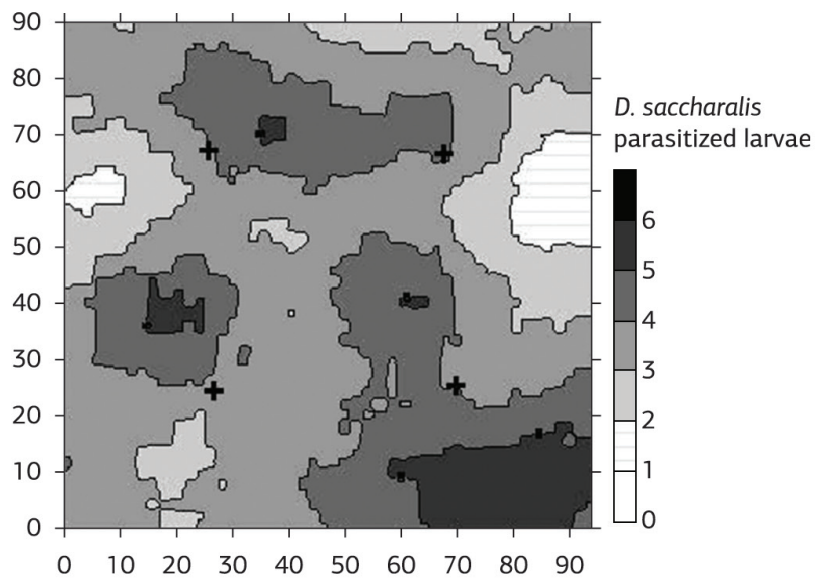

(c)

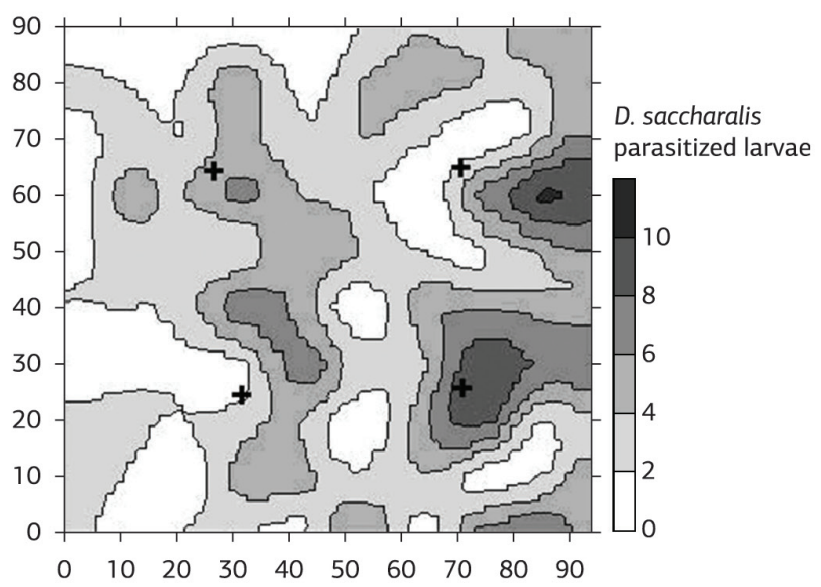

Figure 2. Kriging maps of spatial distribution of Diatraea saccharalis larvae parasitized by Cotesia flavipes, in fields 2 (a), 3 (b) and 4 (c). The (+) marks the releasing point. 
found that even though the parasitized larvae were found up to $64 \mathrm{~m}$ away from the releasing point, most of them were within a distance of $15 \mathrm{~m}$.

However, the dispersal capability of $C$. flavipes estimated in this work differs from the capability found by Botelho et al. (1980) in a work carried out in Brazilian sugarcane fields. These authors estimated the average flight of $C$. flavipes to be $34 \mathrm{~m}$, with the most of them from 25 to $48 \mathrm{~m}$, although in several cases, parasitized larvae have been found up to $140 \mathrm{~m}$ away from the release point.

Although weather conditions might interfere with insect dispersion, as discussed above, the reduction of insect flight capacity from $34 \mathrm{~m}$ (Botelho et al., 1980) to $15-25 \mathrm{~m}$, as observed in the present work, is significant and could be attributed to genetic degeneration due to continuous rearing of the insect in the laboratory.

C. flavipes was introduced in Brazil in 1971 (Teran, 1975, cited by Botelho and Macedo, 2002). However, due to problems in rearing the species in the laboratory and low success observed in the field during that time, the studies were abandoned. In 1974, C. flavipes was reintroduced in the country (Mendonça Filho et al., 1977, cited by Botelho and Macedo, 2002), and since then, it has been intensively reared in the laboratory to be released into infested sugarcane fields. Thus, mating between relatives has occurred, and it is likely that the populations have lost great a deal of their original genetic variability due the high inbreeding levels, resulting in a reduced flight ability. This hypothesis is confirmed by Gu and Dorn (2000), who worked with several C. glomerata populations in the field and the laboratory and found differences among them regarding flight capacity and the ability of females to find hosts. The authors also found that these behavioral characters were inherited. Thus, reproductive isolation during several generations of the Brazilian C. flavipes populations may have resulted in a reduction in flight and the capacity to search for hosts, impairing parasitoid efficiency in the field.

The Kriging maps showing the spatial distribution (Figure 2) confirm that the regions of higher parasitized larvae are near the $C$. flavipes release points. Despite releasing 12,000 parasitoids, and not the typical 6,000, several fields presented low parasitism, such as in the upper quadrant on the right side of assay 2 . Because parasitism success is directly linked to the parasitoid dispersion and its ability to find a host, one of the tools to increase parasitism is to improve parasitoid distribution in the field.

Botelho et al. (1980) estimated that the dispersion of C. flavipes adults varies from 25 to $48 \mathrm{~m}$, and these wasps are frequently released at four points per hectare, approximately $50 \mathrm{~m}$ from each other (Almeida et al., 1997; Botelho and Macedo, 2002). However, the current study revealed that C. flavipes has a smaller dispersal capacity, even when released in a higher quantity than recommended. Possibly, it would be interesting to move the release points to $30 \mathrm{~m}$ from each other because according to our data the dispersal may happen in a $15 \mathrm{~m}$ ray. Thus, parasitoids would be released in approximately nine points per hectare.

\section{REFERENCES}

BOTELHO, P.S.M.; MACEDO, N. Cotesia flavipes para o controle Diatraea saccharalis. In: PARRA, J.R.P.; BOTELHO, P.S.M.; CORREAFERREIRA, B.S.; BENTO, J.M.S. (Ed.). Controle biológico no Brasil: parasitoides e predadores. São Paulo: Manole, 2002. p.409-425.

CAMBARDELLA, C.A.; MOORMAN, T.B.; NOVAK, J.M.; PARKIN, T.B.; KARLEN, D.L.; TURCO, R.F.; KONOPKA, A.E. Field-scale variability of soil properties in central Iowa soils. Soil Science Society of America Journal, v.58, p.1501-1511, 1994. http://dx.doi. org/10.2136/sssaj1994.03615995005800050033x

CAMPOS-FARINHA, A.E.C.; CHAUD-NETTO, J. Biologia reprodutiva de Cotesia flavipes (Cameron) (Hymenoptera: Braconidae). V. Avaliação do número de posturas, prole e razão sexual do parasitóide em relação ao tamanho do hospedeiro (Diatraea saccharalis Fabricius) (Lepidoptera: Pyralidae). Arquivos do Instituto Biológico, v.67, p.249-252, 2002.

CAMPOS-FARINHA, A.E.C.; CHAUD-NETTO, J.; GOBBI, N. Biologia reprodutiva de Cotesia flavipes (Cameron) (Hymenoptera: Braconidae). IV. Discriminação entre as lagartas parasitadas e não parasitadas de Diatraea saccharalis Fabricius (Lepidoptera: Pyralidae), tempo de desenvolvimento e razão sexual dos parasitóides. Arquivos do Instituto Biológico, v.67, p.229-234, 2000.

CANO, M.A.V.; SANTOS, E.M.S.; PINTO, A.S. Produção de Cotesis flavipes para controle da broca-da-cana. In: PINTO, A.S. (Org.). Controle de pragas da cana-de-açúcar. Sertãozinho: Biocontrol, 2006. p.21-24.

CRESSIE, N. Statistics for spatial data. New York: John Wiley, 1991. 900p.

DEGASPARI, N.; MACEDO, N.; BOTELHO, P.S.M.; ARAUJO, J.R.; ALMEIDA, L.C. Predadores e parasitóides de ovos de Diatraea saccharalis em cana-de-açúcar. Pesquisa Agropecuária Brasileira, v.22, p.785-792, 1987.

DINARDO-MIRANDA, L.L. Pragas. In: DINARDO-MIRANDA, L.L.; VASCONCELOS, A.C.M.; LANDELL, M.G.A. (Ed.). Canade-açúcar. Campinas: Instituto Agronômico, 2008. p.349-404.

ELZEN, G.W.; WILLIAMS, H.J.; VINSON, S.B.; POWELL, J.E. Comparative light behavior of parasitoids Campoletis sonorensis and Microplitis croceipes. Entomologia Experimentalis et Applicata, v.45, p.175-180, 1987. http://dx.doi.org/10.1111/j.1570-7458.1987. tb01078.x

EMANA, G.D. Comparative studies of the influence of relative humidity and temperature on the longevity and fecundity of the parasitoid, Cotesia flavipes. Journal of Insect Science, v.7, 2007. Disponível em: <http://www.insectscience.org/7.19>. Accesso em: 1 fev. 2012.

EMANA, G.D.; OVERHOLT, W.A.; KAIRU, E. Comparative studies on influence of relative humidity and temperature on life table parameters of two populations of Cotesia flavipes (Hymenoptera: 
Braconidae). Biocontrol Science and Technology, v. 14, p.595-605, 2004. http://dx.doi.org/10.1080/09583150410001682322

GOLDEN SOFTWARE INC. Surfer for windows. Surfer 7.0. Contouring and 3D surface mapping for scientist's engineers. User's guide. New York: Golden Software, 1999.

GU, H.; DORN, S. Genetic variation in behavioral response to herbivore-infested plants in the parasitic wasp, Cotesia glomerata (L.) (Hymenoptera: Braconidae). Jounal of Insect Behavior, v.13, p.141156, 2000. http://dx.doi.org/10.1023/A:1007723811573

GU, H.; DORN, S. How do wind velocity and light intensity infuence host-location success in Cotesia glomerata (Hym., Braconidae). Journal of Applied Entomology, v.125, p.115-120, 2001. http:// dx.doi.org/10.1046/j.1439-0418.2001.00520.x

KING, E.G.; HARTLEY, G.G. Diatraea saccharalis. In: SINGH, P.; MOORE, R.F. (Ed.). Handbook of insect rearing. New York: Elsevier, 1985. p.265-270.

MACEDO, N.; ARAÚJO, J.R. Efeito da queima da cana-de-açúcar sobre insetos predadores. Anais da Sociedade Entomologica do Brasil, v.29, p.71-77, 2000. http://dx.doi.org/10.1590/S030180592000000100009

PERECIN, D.; BARBOSA, J.C. Afinidade entre distribuiçôes de contágio e Poisson para fins práticos de amostragem. Revista de Matemática e Estatística, v.12, p.107-112, 1994.

PINTO, A.S.; PARRA, J.R.P. Liberação de inimigos naturais. In: PARRA, J.R.P.; BOTELHO, P.S.M.; CORREA-FERREIRA, B.S.; BENTO, J.M.S. (Ed.). Controle biológico no Brasil: parasitoides e predadores. São Paulo: Manole, 2002. p.325-342. PMid:11840490.

POTTING, R.P.J.; SNELLEN, H.M.; VET, L.E.M. Fitness consequences of superparasitism and mechanism of host discrimination in the stemborer parasitoid Cotesia flavipes. Entomologia Experimentalis et Applicata, v.82, p.341-348, 1997. http://dx.doi.org/10.1046/j.15707458.1997.00148.x

SALLAM, M.N.; OVERHOLT, W.A.; KAIRU, E. Dispersal of the exotic parasitoid Cotesia flavipes in a new ecosystem. Entomologia Experimentalis et Applicata, v.98, p.211-217, 2001. http://dx.doi. org/10.1046/j.1570-7458.2001.00776.x

SCAGLIA, M.; CHAUD-NETTO, J.; BROCHETTO-BRAGA, M.R.; CEREGATO, A.S.; GOBBI, N.; RODRIGUES, A. Oviposition sequence and offspring of mated and virgin females of Cotesia flavipes (Hymenoptera: Braconidae) parasitizing Diatraea saccharalis larvae
(Lepdoptera: Crambidae). Journal of Venomous Animals and Toxins, v.11, p.283-298, 2005.

SÉTAMOU, M.; JIANG, N.; SCHULTHESS, F. Effect of the host plant on the survivorship of parasitized Chilo partellus Swinhoe (Lepidoptera: Crambidae) larvae and performance of its larval parasitoid Cotesia flavipes Cameron (Hymenoptera: Braconidae). Biological Control, v.32, p.183-190, 2005. http://dx.doi.org/10.1016/j. biocontrol.2004.09.008

SÉTAMOU, M.; BERNAL, J.S.; LEGASPI, J.C.; MIRKOV, T.E. Parasitism and location of sugarcane borer (Lepidoptera: Pyralidae) by Cotesia flavipes (Hymenoptera: Braconidae) on transgenic and conventional sugarcane. Environmental Entomology, v.31, p.12191225, 2002. http://dx.doi.org/10.1603/0046-225X-31.6.1219

SHAPIRO, S.S.; WILK, M.B. An analysis of variance test for normality: complete samples. Biometrika, v.52, p.591-611, 1965. http://dx.doi. org/10.1093/biomet/52.3-4.591

SILVEIRA NETO, S.; CARVALHO, R.P.L.; PARANHOS, S.B. Manual de ecologia dos insetos. São Paulo: Ceres, 1976. 491p.

SUZUKI, Y.; IWASA, Y.A. A sex ratio theory of gregarius parasitoids. Researchs on Population Ecology, v.22, p.366-382, 1980. http:// dx.doi.org/10.1007/BF02530857

VIEIRA, S.R. Uso de geoestatística em estudos de variabilidade espacial de propriedades do solo. In: NOVAIS, R.F. (Ed.). Tópicos em ciência do solo. Viçosa: Sociedade Brasileira de Ciência do Solo, 2000. p.1-54.

VIEIRA, S.R.; HATFIELD, J.L.; NIELSEN, D.R.; BIGGAR, J.W. Geostatistical theory and application to variability of some agronomical properties. Hilgardia, v.51, p.1-75, 1983.

WEISSER, W.W.; VOLKL, W.; HASSELL, M.P. The importance of adverse weather conditions for behaviour and population ecology of an aphid parasitoid. Journal of Animal Ecology, v.66, p.386-400, 1997. http://dx.doi.org/10.2307/5984

YAMAUCHI, M.N.; GOBBI, N.; CHAUD-NETTO, J.; CAMPOSFARINHA, A.E. Relação entre número de oviposição de Cotesia flavipes (Cam.) e número de descendentes emergidos de seu hospedeiro Diatraea saccharalis (Fabr.). Anais da Sociedade Entomológica do Brasil, v.26, p.87-91, 1997. http://dx.doi.org/10.1590/S0301-80591997000100012

ZHOU, G.; OVERHOLT, W.A. Spatial-temporal population dynamics of Cotesia flavipes (Hemneoptera: Braconidae) in Kenya. Environmental Entomology, v.30, p.869-876, 2001. http://dx.doi. org/10.1603/0046-225X-30.5.869 